\title{
THE SINGER OF THE ECLOGUES
}

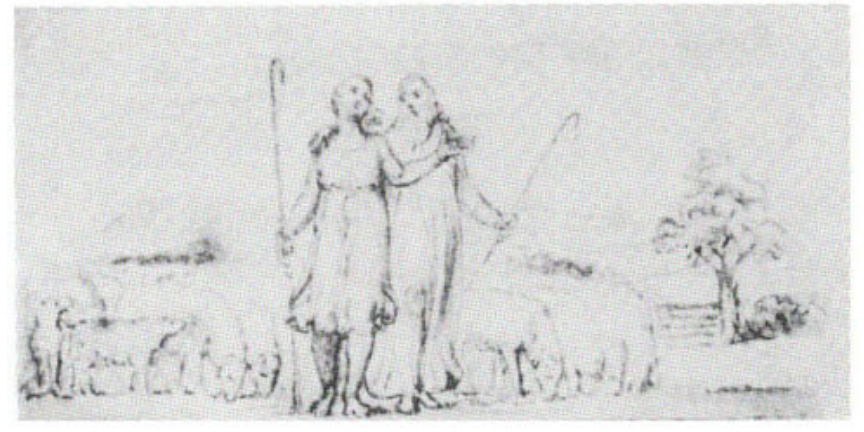





\title{
THE SINGER OF THE Eclogues \\ A STUDY OF VIRGILIAN PASTORAL
}

\section{PAUL ALPERS}

\author{
with a new translation \\ of the Eclogues
}

\author{
University \\ of California \\ Press \\ Berkeley \\ Los Angeles \\ London
}


The Latin text of the Eclogues is taken from Virgil: Opera, edited by R. A. B. Mynors (Oxford Classical Texts), (C) Oxford University Press, 1969. Used by permission of Oxford University Press.

University of California Press

Berkeley and Los Angeles, California

University of California Press, Ltd.

London, England

(C) 1979 by

The Regents of the University of California

ISBN 0-520-03651-4

Library of Congress Catalog Card Number: 77-93465

Printed in the United States of America

$\begin{array}{lllllllll}1 & 2 & 3 & 4 & 5 & 6 & 7 & 8 & 9\end{array}$ 
To my father

BERNARD J. ALPERS

and to the memory of

REUBEN A. BROWER 
